\title{
HYBRID NATURE OF THE ARMED CONFLICT IN THE SYRIAN ARAB REPUBLIC
}

\author{
(C) Pavel S. Melnichuk
}

\author{
Military University of the Ministry of Defense of the Russian Federation, \\ Moscow, Russian Federation \\ colonelmmm@yandex.ru
}

\begin{abstract}
The essence and content of the armed conflict in Syria is considered through the prism of the concept of a hybrid war. The main focus is on the analysis of various points of view on nature, goals, instruments of a hybrid war, presented in the domestic and foreign literature. It is shown that in modern international conflicts, the emphasis is increasingly shifting towards the integrated use of political, economic, information and other non-military measures implemented with the support of the military force. The need to bring the defense strategy of the Russian Federation in line with the challenges and threats of the information era, the development of the Russian strategy for a hybrid war and a counter-hybrid war is justified. It is concluded that it is important to understand the basic principles of an information-psychological war as well as the need for correct and successful use of sign and symbolic means within the framework of an information confrontation.

Key words: nonclassical war, information war, hybrid war, proxy war, "colour revolution", "asymmetrical" war, civil war in Syria, armed conflict, humanitarian mission, special operations forces, cyber-attacks.
\end{abstract}

\section{[П.С. Мельничук Гибридный характер вооруженного конфликта в Сирийской Арабской Респуб- лике]}

Рассматривается сущность и содержание вооруженного конфрликта в Сирии через призму концепции гибридной войны. Основное внимание уделяется анализу различных точек зрения на природу, цели, инструменты гибридной войны, представленных в отечественной и зарубежной литературе. Показано, что в современных международных конфрликтах акцент всё чаще смещается в сторону комплексного применения политических, экономических, информационных и других невоенных мер, реализуемых с опорой на военную силу. Обосновывается необходимость приведения оборонной стратегии РФ в соответствие с вызовами и угрозами информационной эпохи, разработки российской стратегии гибридной и контргибридной войны. Сделан вывод о значимости понимания основных принципов ведения информационно-психологической войны, а также необходимости правильного и успешного использования знаково-символических средств в рамках информационного противоборства.

Ключевые слова: неклассическая война, информационная война, гибридная война, проксивойна, «цветная революция», «ассиметричная» война, гражданская война в Сирии, вооруженный конфрликт, гуманитарная миссия, силы специальных операций, кибератаки.

Pavel S. Melnichuk - Military University of the Ministry of Defense of the Russian Federation, Moscow, Russian Federation.

Мельничук Павел Станиславович - Военный университет Министерства обороны Российской Федерации, г. Москва, Российская Федерация.

Studying the problem of sign and symbolic means and their role in the conduct of an in-information-psychological war and the fight against terrorism, it should be recalled that the use of armed forces to achieve certain goals by military means is a historical phenomenon. At all times, this was associated with wars, military or military-armed conflicts and their specific content (an armed struggle). In order to achieve certain political objectives in the war, including in the fight against terrorism, various means were used: economic, diplomatic, armed forces, information-psychological and others, and their corresponding forms of a struggle. Politicians often resorted to the use of military force as a result of mistakes and lack of success in the use of non-military means. 
Scientific and technical revolution, wide informatization of the whole life of modern society led to fundamental changes in military affairs. Strategic guidelines of many world powers, based on the so-called "concept of a total war," are a thing of the past, since the widespread use of modern powerful weapons will lead to the death of the world civilization.

Today, the world has entered into a series of wars of a new kind, which are aimed at achieving goals without the use of military operations of large military formations, but using new, unconventional forms of struggle.

The war in the modern period of development must be seen as a complex phenomenon that unites various forms of a struggle and their integrated use (political, economic, armed, information-psychological, and others), but at the same time an armed struggle ceases to be an indispensable element of the war.

Back in ancient times, it was found that any goals of a war are always achieved easier and with less loss, the cost of their forces and means, when the enemy loses the ability to counter. This issue is solved, in the main way, in the struggle in the information area. If one of the parties manages to destroy or seriously disrupt the enemy's information area before moving to the war, then victory in it is guaranteed. About 500 years BC, the famous Chinese philosopher and commander Sun Tzu wrote in his "Treatise on the art of war": "In any war, as a rule, the best policy is to capture the State holistically: it is much easier to destroy it. Capturing an enemy army is better than destroying it... To win a hundred victories in a hundred battles is not yet the limit of art. Conquering the enemy without a battle is the crown of art" [7].

One of the main obligatory factors of various methods of a war was an informationpsychological component, now it always occurs with traditional forms of a war. This component exists in the political, economic, diplomatic, and armed struggle. Moreover, the scale of information and psychological impact in all the constituent forms of a struggle is growing continuously. The information-psychological impact as a social phenomenon has deep roots. Long ago the person noticed inexhaustible possibilities and the power of verbal and visual influence in the process of interpersonal and group relations. As social evolution progresses, information from the means of social interaction has developed first into an instrument of influence on the social subject, and subsequently into a type of weapon that can cause certain damage.

Analysis of the process of formation and development of the informationpsychological impact allows to distinguish certain stages in its evolution depending on the development of means of information impact conditionally.

Originally there were attempts to change adequacy of perception of an objective picture (fight, battle, struggle). They were based, as a rule, on the oral and written spreading of rumors, fairy tales, myths and also on the sending of necessary information by means of graphic receptions: drawing, molding, sculpturing, etc. This is the first stage.

The second stage involved with the active use of printed sources of information from isolated cases to their mass use. Prominent political and military figures as well as scientists of this period, such as Hernán Cortés, Niccolò Machiavelli, Gustave Le Bon, Napoleon Bonaparte, Carl von Clausewitz, Erich Ludendorff, Paul von Hindenburg and many others made a significant contribution to the emergence of theoretical thought and the practice of the information-psychological impact.

The third stage (the mid-19th-20th centuries). Fundamental changes of methods and forms of the information-psychological influence are associated with the discovery of electricity as well as the invention of the telegraph (1849), the telephone (1876) and especially the radio (1895). Only after the appearance of the first telegraph lines information agencies were created. They collected and disseminated the appeared information primarily of a political, economic and military nature. This stage was marked by the use of 
photo information (the mid-19th century), and by the use of cinema with the beginning of the 20th century.

The fourth stage. $70-80$ of the 20th century, when the image transmission device was invented, the introduction of television systems began, which by the 1980s had taken the form of telecommunication systems. This new tool significantly changed the nature of the information-psychological impact itself, made it possible to visualize, actualize information impacts.

The fifth stage. With the introduction of personal electronic-computer tools and their switching system, another breakthrough in the information-psychological impact occurs. A new stage of the information-psychological impact is coming with the use of personal computers and the global computer information and telecommunication network "Internet".

Thus, in the course of improvement of means of influence, there is a transformation of means, and respectively of methods, ways and forms of the information-psychological influence. They turn into a bloodless, nonlethal and latent defeat, causing significant and hidden information damage.

At present, it is quite easy to enter the information sphere of any country, the information sphere of its political and state institutions through the usual channels of information dissemination such as television, radio, print media as well as the global computer network of the Internet and to use them for the information-psychological impact. We can see that the information-psychological impact has become the most important content of the armed struggle, it performs specific functions in all methods of warfare.

Examples of the use of information weapons (electronic warfare equipment, highfrequency generators, computer backdoors and viruses, shapeshifting programs, etc.) known from the experience of recent local wars and various military conflicts gave a good result. Special means of the information-psychological influence available in various States, capable of creating holographic images in the atmosphere, imitators of voices and sounds capable of making voice messages, giving them on behalf of heads of different countries and disseminating them through electronic mass media, constantly modernized and, according to experts, when exposed to people at 10 percent efficiency, they can cause a state of panic in any, even the most well-united and organized team.

Thus, the information-psychological war (as well as countering terrorism) is an important tool for prevention, and in the event of a war, one of the elements of ensuring its conduct. It can have a significant impact on the moral and psychological state of the population and military personnel of the enemy, of neutral and friendly States, on the course and outcome of the war as a whole.

The essence of the information-psychological influence should be understood as the influence on the individual and public consciousness by military, propaganda, psychological or other means, which causes the transformation of the psyche, contributes to declining morale, and forces to stop hostilities and resistance in the conditions of a modern war.

The purpose and result of the information-psychological impact is the restructuring of the psyche of the target audience, the achievement of certain mental shifts and changes affecting the behavior of the target audience.

The formation of an information-psychological war in the modern sense occurred during the First World War and the revolutionary events caused by it. It is characteristic that the first classical propaganda works, such as "Public Opinion" by W. Lippman (1922), "Propaganda" by E. Bernays (1928) appeared precisely in the 1920s.

In 1937, the Institute for Propaganda Analysis was established in New York, within the framework of which seven typical propaganda techniques were identified, also known as the "propaganda code": name-calling, glittering generalities, transfer, testimonial, plain folks, card stacking and bandwagon. Currently, these techniques continue to be widely 
used in the conduct of information-psychological wars. It should be said that tactics, methods, means and techniques of propaganda have not changed since that time. However, new means of communication emerged that have greatly enhanced the effectiveness of information-psychological weapons.

Thus, many scientists in their works, exploring the sign and symbolic means of conducting an information-psychological war, revealed the essence of an information war (Elvira Spirova in her hermeneutic circle [6], Valery Solovei in the book "Absolute Weapons" [5], Elliot Aronson and Anthony Pratkanis [1], Gregory Gutner [3], Carl von Clausewitz [4]).

According to Jean Baudrillard, "all manipulation hypotheses are reversible in an infinite closed system. After all, manipulation is a shaky causality, in which positive and negative positions generate and overlap each other with causality, in which there is no longer either assets or liabilities." In his opinion, "television watches us, television alienates us, television manipulates us, television informs us... At the same time, we remain hostages of the analytical concept of media, the concept of an active and effective external agent, the concept of "promising" information, in which the point of departure is the horizon of real and meaning. None of this is in the television "picture." This picture offers nothing, which in itself is only a screen or even only a miniature terminal, located actually in your head; the screen is you, and television watches you, it transistorizes all your neurons and scrolls like a mag-tape, the tape, but not the image" [2].

However, it is also true that people manipulate each other using words, which are the main manipulative tool.

The sign is the main concept of semiotics. There are two main definitions of the sign, with which different approaches to understanding the nature of the sign and its place in cognition are associated. According to the first definition (the Swiss linguist Ferdinand de Saussure), the sign is a dual entity, which is a unity of a plan of expression and a plan of content. According to the second (the American philosopher Charles Sanders Peirce), the sign is a material object that replaces or represents another object or phenomenon in human activity.

The Sossure sign in Foucault's interpretation acquires much wider meaning and implied sense, perhaps more than what Sossure could expect, even resorting to semiotics. The language becomes a discourse when it loses the ability to mark similarities and becomes one of the methods of naming in an objective form. Learning the language, Foucault goes from archaic analysis of various flexions to the grammar of universals, because the language was created and developed inseparably from ideology, it always contains prejudiced attitude. The language of the Classical period is a reflection of the ideology of this time. The same is true regarding other eras. Jacques Derrida develops Saussure's idea of the sign, but does not agree with his main concept of the sign. The philosopher believes that the meaning in the sign is not full. For example, when someone talks about a creature with four paws that barks, there is no definite acoustic image of a "dog" that would coincide with some particular mental pattern of a "dog." There is not only true "dog," so the value cannot be completed in the sign. Moreover, acoustic and mental representations vary among every person. Symbolic is the conscious use of a language as a sign system. Writing, speaking, gestures, sign language, all this is based on symbolic. Symbolic represents culture, consciousness, mind as well as what is opposed to all this (nature, body, subconscious). In symbolic, there is a phenomenological subject involved in creating meaning.

The result of the further development of the sign theory was a linguistic turn. On the one hand, the linguistic turn in philosophy began when self-representation became an infinite reflection of the subject in many mirrors. This means that subjectivity has ceased to be a simple relationship between itself and nature. The results of the linguistic turn in the 
West became visible in the growing popularity of Freud, Jung and Saussure at the turn of the century as well as structuralist theories in the middle of the 20th century. Saussure showed that this is a language, but not an individual, constructs subjectivity and culture. Poststructuralists, in turn, continued his ideas and put forward the idea that interpretation is always relative and subjective, and there is nothing outside the language.

When studying the works of Freud and Jung, psycholinguists came to the conclusion that psychology was also involved in a linguistic turn. As scholars, Freud and Jung were not interested in the language as a sign system relating to the world of things at all, but at the same time were extremely interested in the language as images related to the psyche.

At the turn of the 20th and 21st centuries, in the understanding of the French philosopher Jean Baudrillard, "there is no more mirror between being and its reflection, between the real and its concept. /.../ Real is made on the basis of miniature cells of matrices and memory devices, management models and can be reproduced an unlimited number of times" [2].

Speaking about sign and symbolic means of conducting an information-psychological war, one cannot fail to touch on the issue of their widespread use in terrorism.

Terrorism must be defined before the topic could be considered. However, this issue presents some complexity. Thus, Wilkins does not exaggerate when he writes that the number of definitions of terrorism corresponds to the number of works devoted to this topic $[19$, p. 2]. By 1984, Alex Schmidt had managed to collect 109 different definitions of terrorism [15, pp. 119-158]. The scientist writes that he cannot offer any single correct or true definition of terrorism. Terrorism is an abstract phenomenon that has no entity to detect or describe. In his opinion, the authors of works on terrorism spilled almost as much ink as the blood of innocents was spilled by terrorists $[14,15]$. The views of scientists on this issue really vary greatly.

George Fletcher and Jeremy Waldron question the need to spend time searching for the only correct definition. In the context of terrorism, Fletcher recalls the phrase of Potter Stewart, a member of the US Supreme Court, about pornography: "I will find out when I see" $[9,17]$. As long as people understand and intuitively feel what is terrorism and what is not, no definition of terrorism with a description of all its signs will be able to take root.

Any acts could not be attributed to terrorism only on the basis of simple criteria. Fletcher explores the possibility of identifying eight variables of terrorism: cruelty, intent, victims, criminals, convincing motive, organization, theatricality, and, finally, what the scientist calls "neither guilt nor pity" among criminals. Turning to L. Wittgenstein's work on family similarities, the scientist insists that the terrorist act does not have the necessary signs or certain criteria. Similar actions can be both similar and different to each other. There is no common denominator for all terrorist acts except perhaps theatricality [9].

The Oxford Dictionary provides the following definition of terrorism. It is cruelty and humiliation, especially to achieve political objectives [11]. Interestingly, L. Trotsky also expresses his opinion in his book "Terrorism and Communism": terrorism is cruelty aimed at intimidating and, accordingly, achieving political objectives [16]. It is obvious, however, that many actions in a conventional war also can be cruel and intimidating and they can pursue certain political objectives. Many modern theorists use a huge number of inclusive definitions of terrorism, which erase the distinction between it and other forms of political cruelty. Their goal is to neutralize these differences, thus proving that terrorism is no worse than any other form of cruelty that is accepted by the international community.

Many terrorists consider that the very concept of terrorism or at least its modern use was deliberately fabricated so that it could serve the political interests of the strongest powers in the international arena, in particular the United States. Thus, America's classification of individuals, groups, organizations or countries as terrorist is biased and unjust 
[10]. This form of cruelty does not have a single significant sign that would distinguish it from all the others that the United States or its allies have ever used. A similar opinion, for example, is held by the American linguist Noam Chomsky [8]. If so, the moral assessment of any use of force is based entirely on the fairness of its cause, and not on the means used for these purposes.

There is also a question of what should be considered as terrorism, whether this is exclusively a category of action or whether it includes cruel methods. Michael Waltzer in his work "Just and Unjust Wars" provides a prime example of the strict definition of terrorism, which is referred to in all discussions on this topic. He writes that "terrorism (as opposed to guerrilla actions or political assassination) is a special form of political cruelty, implying the deliberate, indiscriminate killing of unarmed non-combatants in order to spread fear of deadly peril among the civilian population as a strategy for achieving political objectives [18, p. 197; 203].

Anglo-American Liberal States, especially the United States and Great Britain, took a firm public position against any manifestation of terrorism and launched a whole campaign against this, sometimes very cruel. The culmination of all this was the "War against Terrorism" by the president of the United States George Bush. The rhetoric of heads of States, deliberately blurred and uncertain, erases differences, perhaps inadvertently, but often in a staged manner, and does not have any analytical accuracy. Western States and their leaders use the term "terrorism" inconsistently when talking about cruelty against their citizens, and they are probably very disingenuous in assessing their own actions. In their speeches they do not share an assessment of the causes (their fairness and injustice) and an assessment of the legitimacy of the means used to achieve their goals. None of these well-known truths, however, can lead to the conclusion that condemnation of terrorism as well as conversations about waging war are manifestations of hypocrisy from the West.

The threat of the terrorist organization ISIL introduced an ideology into the debate on the nature of terrorism, the word that has rarely been raised in this context before. Theorists, journalists and scientists began to argue about what values and beliefs motivate the actions of terrorists. US Brigadier General Michael K. Nagata, commander of the US Special Forces in the Middle East, admitted that "we did not destroy the idea, we do not even understand what this idea is" [12, p. 186].

Al-Qaida and other terrorist organizations saw enormous potential in cyberspace for propaganda purposes. And even pornography was not so bad when it was able to help to attract new members to its ranks. Among the most conservative terrorists, the addiction to watching such content has always been considered as a sin, but easy access to everything in the Internet space allowed many Muslims to receive a kind of absolution of sins. By visiting sites such as Quran.com or Islam.org, you receive a message from a clergyman who absolves you of all your sins. Since the early 1990s, Al-Qaida has established a mechanism of lust and forgiveness for it. Members and leaders of the organization have seen that many young people need guidance on what is good and how to eliminate vice from their lives. In this, they saw a mechanism to attract new members to their ranks, who should be convinced that Islam was mired in pornography, Western values and a thirst for money. And the only solution was absolution of sins by studying a new version of Islam, which was grown up by blood, struggle and battles, as the followers of the prophet Muhammad did in the 17th century. This is one of numerous examples of how cyberspace gradually became a kind of battlefield [13, pp. 24-25].

But for the first time, it was neither Al-Qaida nor ISIL that began to consider war in cyberspace. These were the Palestinians during the second intifada. Mutual attacks in cyberspace gave rise to a kind of "electronic intifada," which continues to this day [13, p. 29]. 
Thus, it can be concluded that it is important to understand the basic principles of an information-psychological war as well as the need for correct and successful use of sign and symbolic means in the framework of an information confrontation. Modern trends in science have a pronounced anthropocentric character, which requires researchers to pay more attention to the influence of the objects of these studies on a person, his psyche and cognitive features of the world perception.

\section{Лumepamypa}

1. Аронсон Э., Пратканис Э.Р. Эпоха пропаганды: механизмы убеждения, повседневное использование и злоупотребление. Перераб. изд. СПб.: ПраймЕВРОЗНАК, 2003.

2. Бодрийяр Ж. Симулякры и симуляции / Ж. Бодрийяр; [пер. с фр. А. Качалова]. М.: Издательский дом «ПОСТУМ», 2016. 240 с.

3. Гутнер Г.Б. Знак. Новая российская энциклопедия в 12 томах, под ред. А.Д. Некипелова.

4. Клаузевиц К.фон. Принципы ведения войны. Пер. с англ. Л.А. Игоревского. М.: ЗАО Центрполиграф, 2009. 220 с. (Хроники военных сражений).

5. Соловей В.Д. Абсолютное оружие. М.: Издательство «Э», 2016.

6. Спирова Э.М. Герменевтический круг. Знание. Понимание. Умение. №2М.: Московский гуманитарный университет, 2006.

7. Сунь-Цзы. Трактат о военном искусстве. М.: Издательство «Эксмо», 2018. 78 с.

8. Chomsky N., 9-11 New York: Seven Stories Press, 2001.

9. Fletcher $G$. The Indefinable Concept of Terrorism. Journal of International Criminal Justice 4.5 (2006), pp. 894-911.

10. Held V., Terrorism, Rights, and Political Goals, in Primoratz, Terrorism, pp. 65-79.

11. Hornby A.S., Oxford Student's Dictionary for Hebrew Speakers. Tel-Aviv, Kernerman, 1991.

12. Nance M.W., Defeating ISIS. Skyhorse publishing. 2017.

13. Nance M.W., Sampson C.; Hacking ISIS. How to destroy the cyber jihad. Skyhorse publishing. 2017.

14. Schmid A.P. and Jongman A.J. Political Terrorism: A Research Guide to Concepts, Theories, Data Bases and Literature, 2nd edn. Amsterdam, North HollandPublishing, 1988.

15. Schmid A.P. Political Terrorism: A Research Guide to Concepts, Theories, Data Bases and Literature. Amsterdam, North-Holland Publishing, 1984.

16. Trotsky L.D.A Defense of the Red Terror, in Primoratz, Terrorism, pp. 31-43.

17. Waldron J. The Journal of Ethics, Vol. 8, No. 1, Terrorism (2004), pp. 5-35.

18. Walzer M., Just and Unjust Wars, Basic Books, 1997.

19. Wilkins T.B. Terrorism and Collective Responsibility. London, Routledge, 1992.

\section{References}

1. Aronson E., Pratkanis A.R. Epokha propagandy: mekhanizmy ubezhdeniia, povsednevnoe ispolzovanie i zloupotreblenie. [Age of propaganda: mechanisms of persuasion, everyday use and abuse]. Redaction. Saint Petersburg: Prime EUROZNAC, 2003 (in Russian).

2. Baudrillard J. Simuliakry i simuliatsii. [Simulacra and simulations]. J. Baudrillard; [translated from French by A. Kachalov]. Moscow: Publishing House "POSTUM", 2016. 240 p. (in Russian). 
3. Gutner G.B. Znak. Novaia rossiiskaia entsiklopediia $v 12$ tomakh, pod red. A.D. Nekipelova. [Sign. New Russian encyclopedia in 12 volumes, eds by A.D. Nekipelov].

4. Clausewitz von C. Printsipy vedeniia voiny. Per. s angl. L.A. Igorevskogo. [Principles of warfare. Translated from English by L.A. Igorevsky]. Moscow: ZAO Centerpoligraph, 2009. 220 p. (Chronicles of military battles) (in Russian).

5. Solovei V.D. Absoliutnoe oruzhie. [Absolute weapon]. Moscow: Publishing House "E," 2016 (in Russian).

6. Spirova E.M. Germenevticheskii krug. Znanie. Ponimanie. Umenie. [Hermeneutic Circle. Knowledge. Understanding. Skill]. No. 2. Moscow: Moscow University of Humanities, 2006 (in Russian).

7. Sun Tzu. Traktat o voennom iskusstve. [Treatise on the art of war]. Moscow: Publishing House "Eksmo", 2018. 78 p. (in Russian).

8. Chomsky N., 9-11 New York: Seven Stories Press, 2001.

9. Fletcher G. The Indefinable Concept of Terrorism. Journal of International Criminal Justice 4.5 (2006), pp. 894-911.

10. Held V., Terrorism, Rights, and Political Goals, in Primoratz, Terrorism, pp. 65-79.

11. Hornby A.S., Oxford Student's Dictionary for Hebrew Speakers. Tel-Aviv, Kernerman, 1991.

12. Nance M.W., Defeating ISIS. Skyhorse publishing. 2017.

13. Nance M.W., Sampson C.; Hacking ISIS. How to destroy the cyber jihad. Skyhorse publishing. 2017.

14. Schmid A.P. and Jongman A.J. Political Terrorism: A Research Guide to Concepts, Theories, Data Bases and Literature, 2nd edn. Amsterdam, North HollandPublishing, 1988.

15. Schmid A.P. Political Terrorism: A Research Guide to Concepts, Theories, Data Bases and Literature. Amsterdam, North-Holland Publishing, 1984.

16. Trotsky L.D.A Defense of the Red Terror, in Primoratz, Terrorism, pp. 31-43.

17. Waldron J. The Journal of Ethics, Vol. 8, No. 1, Terrorism (2004), pp. 5-35.

18. Walzer M., Just and Unjust Wars, Basic Books, 1997.

19. Wilkins T.B. Terrorism and Collective Responsibility. London, Routledge, 1992. 